\author{
A.R. Yeshkeyev, M.T. Omarova \\ Ye.A. Buketov Karaganda State University, Kazakhstan \\ (E-mail: modth1705@mail.ru)
}

\title{
Central types of convex fragments of the perfect Jonsson theory
}

In this paper, the central types of convex fragments of the perfect Jonsson theory are considered. The main goal of this paper is to redefine the A.D. Taimanov's question for complete theories in the sphere of Jonsson fragments of formula-definable subsets of a Jonsson fixed theory's semantic model. Also the relationships between the center and Jonsson theory in the permissible enrichment of signature are considered. Herewith, the considered theories are hereditary. It is also assumed that an algebraic closure coincides with a definable closure. Within the framework of the above restrictions for the considered Jonsson theory, results on the existence of core models for such theories were obtained.

Keywords: Jonsson theory, semantic model, existentially prime theory, pregeometry, model companion, core model.

In the investigation of inductive theories, the study of Jonsson theories and their classes of models is one of the actual problems of the Model theory and universal algebra concurrently. This is due to the fact, that Jonsson theories are a subclass of inductive theories and the Jonsson conditions are satisfied for all known and important examples from algebra. For example, these are the theories of group, abelian groups, fields of fixed characteristic, of the modules, linear orders and Boolean algebras. The basic concepts and methods of Jonsson theories' studying were defined as the subject of research after the publication of an original B. Jonsson's works [1,2], in which he defined some conditions for algebraic systems. Jonsson conditions are natural algebraic requirements that arise when we studying a wide class of algebras. All the above examples are important both in algebra and in various areas of mathematics. As can be seen, from the listed list, the scope of application of the technique developed for the study of Jonsson theories can be quite wide.

We will adhere to the standard designations adopted in Model theory [3]. The class of inductive theories is wider than the class of Jonsson theories. As Jonsson theories are, generally speaking, uncomplete theories, this causes additional difficulties and accordingly requires the creation of their own methods of study from researchers. To date, the main of existing method's of study is a semantic method. Its essence is a checking properties of first-order sentences which belong to the Jonsson theory's center with respect to the pre-image, that is, with respect to the Jonsson theory itself. The first-order formulas subsets in the existentially closed submodels of the considered Jonsson theory's semantic model are automatically compared. Moreover, in the case of perfect theories, sufficiently a complete descriptions of such theories and their classes of models were obtained. All this is reflected in the book [2].

We have already noticed, that the class of Jonsson theories, as a proper subclass of inductive theories, is quite wide. Also in algebra there are many natural examples of algebras whose axioms satisfy the axioms of Jonsson theories. But still, it's still a fairly wide class if we take into account its uncompleteness, so if we add the convexity condition, then although the class is narrowed, we still have such classical examples as group theory, theory of Abelian groups, theory of fields of fixed characteristic and many other classical algebraic objects that are Jonsson and convex concurrently.

As a rule, we can consider two different ways to define an arbitrary Jonsson theory. In the first case, we must consider the $K$ class of models for some signature. Next, select all $\Gamma$-sentences such that they are true in every model of this class, where $\Gamma$-is the kind of sentences in the language of this signature. For example, $\Gamma=\forall$, $\Gamma=\exists$ or their various combinations that are negotiated. The second way is a choose sets of sentences as initial or axioms. The set of sentences that is equivalent to $T h(K)$, is called the set of axioms for $K$. Examples are the axioms of group theory, abelian groups, full groups and torsion-free groups, etc. In both cases, the considered class must satisfy the Jonsson conditions. This can be achieved by various means. In particular, an important subclass of the considered class of models is the class of existentially closed models. The following fact is true, that the set of all $\forall \exists$-sentences which true in existentially closed models form a Jonsson theory. Therefore, both 
of the above methods in the obvious way by closing the subclass of existentially closed models with respect to amalgam and the property of joint embedding will determine the Jonsson theory. Also We can move from an arbitrary complete theory to the corresponding Jonsson theory using the following method: the addition of some additional symbols to the signature. As a rule, three types of symbols are used: predicates, function symbols and constants. But at the same time, the enrichment of signature must preserve the important certain theoretic model qualities of the old signature. Without less generality depending on the specific problem, such enrichments of a signature will be called admissible. For example, the requirements of preserving the stability of a theory or a type definability. We say that the conservative extension of the theory $T$ in the language $L$ is the theory $T^{\prime} \supseteq T$ in the extended language $L^{\prime} \supseteq L$ such that any model $A$ of theory $T$ can be enriched to model $A^{\prime}$ of theory $T^{\prime}$. It is known that any theory $T$ has a conservative extension $T^{\prime}$, which is inductive and admits elimination of quantifiers. It is also known that every theory $T$ has a conservative extension that is universal and model-complete.

Moreover, it can be noted that if the complete theory is considered with infinite models, then both of these extensions for this theory are Johnsonian ones.

Thus, all of the above suggests that the study of model-theoretic properties of Jonsson theories is an important task.

We give the necessary definitions related to the Jonsson theories [4].

Definition 1. A theory $T$ has the property of joint embedding if for any models $A, B$ of the theory $T$ there is a model $M$ of the theory $T$ and isomorphic embeddings $f: A \rightarrow M, g: B \rightarrow M$.

Definition 2. A theory $T$ has the amalgam property if for any models $A, B, C$ theories $T$ and isomorphic embeddings $f_{1}: A \rightarrow B, f_{2}: A \rightarrow C$ there are such $M \models T$ and isomorphic embeddings $g_{1}: B \rightarrow M$, $g_{2}: B \rightarrow M$, such that $g_{1} \circ f_{1}=g_{2} \circ f_{2}$.

A theory is inductive if it is stable with respect to the union of chains. The following theorem is known:

Theorem 1. (Cheng-Los-Sushko). A theory is stable with respect to the union of chains if and only if it is $\forall \exists$ - axiomatizable, i.e. is equivalent to the set of $\forall \exists$ - sentences.

Definition 3. A theory $T$ is Jonsson if:

1) Theory $T$ has infinite models;

2) Theory $T$ is inductive;

3 ) Theory $T$ has the joint embedding property $(J E P)$;

4) Theory $T$ has the property of amalgam $(A P)$.

As noted above, the following theories are examples of Jonsson theories:

1) groups;

2) Abelian groups;

3) Boolean algebras;

4) linear orders;

5) characteristic fields (- a prime number or zero);

$6)$ ordered fields.

Definition 4. Jonsson theory $T$ is called a perfect theory, if each a semantic model of theory $T$ is saturated model of $T^{*}$.

Definition 5. Let $T$ be a Jonsson theory. Then a companion Jonsson theory $T$ is a theory $T^{*}$ of the same signature if:

1) $\left(T^{*}\right)_{\forall}=T_{\forall}$;

2) for any Jonsson theory $T^{\prime}$, if $T_{\forall}=T_{\forall}^{\prime}$, then $T^{*}=\left(T^{\prime}\right)^{*}$.

3) $T_{\forall \exists} \subseteq T^{*}$.

The natural interpretations of the companion $T^{\#}$ are $T^{*}, T^{0}, T^{f}, T^{M}, T^{e}$, where the $T^{0}$ is the Kaiser shell, the $T^{*}$ is the center, the $T^{M}$ is the model companion, the $T^{f}$ is a finite forcing companion in the Robinson's sence, the $T^{e}$ is an elementary theory of all existentially closed models' of class of $T$.

Definition 6 . A theory is called convex if for any its model $A$ and for any family $\left\{B_{i} \mid i \in I\right\}$ of substructures of $A$, which are models of the theory $T$, the intersection $\bigcap_{i \in I} B_{i}$ is a model of $T$.

Definition \%. If a theory is strongly convex, then the intersection of all its models is contained in some of its models.

This model is called a core model of this theory.

Definition 8 . The inductive theory $T$ is called an existentially-prime if:

1) It has an algebraically prime model. The class of its $A P$ denote by $A P_{T}$;

2) Class $E_{T}$ is not trivial intersects with class $A P_{T}$, i.e. $A P_{T} \cap E_{T} \neq 0$. 
Since Jonsson theories are inductive, we can consider Jonsson theories which an existentially prime and then among them we can consider the convex theories. The most striking example, which is showing, that such examples a lot of is an example of group theory. This example is characterized in that it is an example of an imperfect Jonsson theory. In the case of theory of Abelian groups, we have a perfect example of a convex Jonsson theory.

Definition 9. A signature model of a given theory (structure) is called a core if it is isomorphic to an unique substructure of each model of the given theory.

The core structure that is the model of the theory of a given signature will be called the core model of theory.

Definition 10. Let $X \subseteq C$. We will say that a set $X$ is $\nabla-c l$-Jonsson subset of $C$, if $X$ satisfies the following conditions:

1) $X$ is $\nabla$-definable set (this means that there is a formula from $\nabla$, the solution of which in the $C$ is the set $X$, where $\nabla \subseteq L$, that is $\nabla$ is a view of formula, for example $\exists, \forall, \forall \exists$ and so on.);

2) $\operatorname{cl}(X)=M, M \in E_{T}$, where $c l$ is some closure operator defining a pregeometry [5; 289] over $C$ (for example $c l=a c l$ or $c l=d c l)$.

Definition 11. If $(X, c l)$ is a Jonsson pregeometry, we say that $A$ is Jonsson independent if $a \notin \operatorname{cl}(A \backslash\{a\})$ for all $a \in A$ and that $B$ is a $J$-basis for $Y$ if is $J$-independent and $Y \subseteq \operatorname{acl}(B)$.

Definition 12. We say that a $J$-pregeometry $(X, c l)$ is $J$-geometry if $\operatorname{cl}(\emptyset)=\emptyset$ and $\operatorname{cl}(\{x\})=\{x\}$ for any $x \in X$.

If $(X, c l)$ is a $J$-pregeometry, then we can naturally define a $J$-geometry. Let $X_{0}=X \backslash \operatorname{cl}(\emptyset)$. Consider the relation $\sim$ on $X_{0}$ given by $a \sim b$ if and only if $\operatorname{cl}(\{a\})=\operatorname{cl}(\{b\})$. By exchange, $\sim$ is an equivalence relation. Let $\widehat{X}$ be $X_{0} / \sim$. Define $\widehat{c l}$ on $\widehat{X}$ by $\widehat{c l}(A / \sim)=\{b / \sim: b \in \operatorname{cl}(A)\}$.

Definition 13. Let $(X, c l)$ be $J$-pregeometry. We say that $(X, c l)$ is trivial if $c l(A)=Y_{a \in A} c l\{a\}$ for any $A \subseteq X$. We say that $(X, c l)$ is modular if for any finite-dimensional closed $\operatorname{Jdim}(A \cup B)=\operatorname{Jdim}(A)+J \operatorname{dim}(B)-$ $-\bar{J} \operatorname{dim}(A \cap B)$.

We say that $(X, c l)$ is locally modular if $\left(X, c l_{a}\right)$ is modular for some $a \in X$.

Definition 14. We say that $(X, c l)$ is modular if for any finite-dimensional closed $A, B \subseteq X$

$$
\operatorname{dim}(A \cup B)=\operatorname{dim} A+\operatorname{dim} B-\operatorname{dim}(A \cap B)
$$

Let $T$ - be an arbitrary Jonsson theory in the language of signature $\sigma$. Let $C$ be the semantic model of T. $A \subseteq C$. Let $\sigma_{\Gamma}(A)=\sigma \cup\left\{c_{a} \mid a \in A\right\} \cup \Gamma$, where $\Gamma=\{g\} \cup\{c\} \cup\{P\}$. Consider the following theory, where $T_{\Gamma}(A)=T h_{\nabla}(C, a)_{a \in A} \cup\{g(a)=a \mid a \in A\} \cup g(c) \cup T_{g} \cup\{P(c)\} \cup\left\{{ }^{\prime \prime} P \subseteq \subseteq^{\prime \prime}\right\}$, where $T_{g}$ - expresses the fact, that for any model $\left(M, g^{M}\right) \models T_{g}$ takes place:

1) $g^{M}$ - automorphism $M$

2) $\left\{m \in M \mid g^{M}(m)=m\right\}$ is a universe of some existentially closed submodel $M$ of the semantic model $C$ of theory $T$ of signature $\sigma$.

There is question that is to find the condition for preserving the definability of a type with the appropriate stability obtained as a result of enriching the language.

In connection with the above question, well known are the results of T.G. Mustafin [6] and E.A. Palyutin [7] about new types of stability for complete theories.

Also in the work [7] had noted that an each of above enrichment (unary predicate, automorphism, constant) is satisfied to admissibility property that is saved the definibality of type in the frame of new kind of stability.

For the predicate $P$ we write the expression $\left\{{ }^{\prime \prime} P \subseteq^{\prime \prime}\right\}$, which is essentially an infinite set of sentences, this mean that an interpretation of the symbol $P$ is an existentially closed submodel in signature $\sigma$. Due to incompleteness, we do not write down the exact connection between the elements $\Gamma=\{g\} \cup\{c\} \cup\{P\}$, but they are supposed to be consistent within the framework of the theory $T_{\Gamma}(A)$.

The theory $T_{\Gamma}(A)$ is not necessarily complete. Suppose that it is Jonsson, i.e. it has a center $T_{\Gamma}^{*}(A)$. We consider all replenishment of the center $T^{*}$ of the theory $T$ in the new signature $\sigma_{\Gamma}$, where $\Gamma=\{g\} \cup\{c\} \cup\{P\}$.

By virtue of the Jonssoness theory $T_{\Gamma}(A), T^{*}$ it will also be a Jonsson theory, generally speaking, not a complete theory, then its center, respectively, exists and we denote it by $T^{c}$. With the restriction of $T^{c}$ to the signature $T_{\Gamma}(A) \backslash\{c\}$, the theory $T^{c}$ becomes a complete type. This type is called the central type of the theory $T$ relative to the given enrichment $T_{\Gamma}(A) \backslash\{c\}$.

Unfortunately, even while preserving the definability of the type, as mentioned above, not all Jonsson theories preserve their Jonssoness with allowable enrichment of the signature, for example, field theory does not 
necessarily admit amalgam when enriching with a single predicate, those there is a counterexample. Therefore, we will assume that the closure operator $c l$ will define a modular geometry. We note that, in particular, the algebraic closure operator in the sense of fields does not generate a modular pregeometry.

Definition 15. If $X=C$ and $(X, c l)$ is a modular, then the Jonsson theory $T$ is called modular.

The following assertions will be used to prove the main assertions in the framework of the perfect Jonsson theory $T$ regarding the connection of lattices of formulas $E_{n}(T)$ and the Boolean algebras $F_{n}(T)$.

Fact 1 [4]. For any Jonsson theory $T$ the following conditions are equivalent:

1) $T$ is perfect;

2) $T^{*}$ is model complete.

Fact 2 [4]. For any complete for $\exists$-sentences Jonsson theory $T$, the following conditions are equivalent:

1) $T^{*}$ is model complete;

2) for each $n<\omega, E_{n}(T)$ is the Boolean algebra, where $E_{n}(T)$ is a lattice of $\exists$-formulas with $n$ free variables.

At the moment, we do not know the amalgama criterion when enriching the signature, so we will work under some assumptions.

Next we give the following definitions:

It is well known that the perfect Jonsson theory can be studied using of the first-order properties of the center of this theory and its semantic model, since the center of the Jonsson theory is the model companion of it. Imperfect Jonsson theories at the moment have not been studied. For example, a bright example of this fact is the theory of all groups. We know that this theory is Jonsson, but does not have a model companion, and the structure of its semantic model is unknown to us. In this work, in order to avoid the above mentioned situation with non amalgamation under enrichment, we will consider a special subclass of Jonsson theories, namely, hereditary Jonsson theories.

We introduce the following definitions necessary for the above purposes.

Definition 16. The Jonsson theory is said to be hereditary, if in any of its admissible enrichment any expansion of it in this enrichment will be Jonsson theory.

All considered Jonsson theories in the future under this article are assumed to be hereditary.

Let $T$ be a perfect, complete for existential sentences, Jonsson theory of signature $\sigma_{\Gamma}(A)$.

Let $A$ is $\nabla$-cl-Jonsson subset of $C, C$ is semantic model of the theory $T, \nabla=\forall \exists, c l=a c l$, with $a c l=d c l$ and a pregeometry generated by $c l$ on the set of all subsets of $C$ is modular. $\operatorname{cl}(X)=M, M \in E_{T}$. We consider the theory $T h_{\forall \exists}(M)$, which we call the fragment of the set $A$ and denote by $\operatorname{Fr}(A)$.

We formulate the question of A.D. Taimanov, given that this problem was defined for complete theories.

Namely, in studying the properties of models of the first order complete theories information about the Boolean algebras (Lindenbaum-Tarsky algebras) $F_{n}(T)$ is usually, $n \in \omega$ [8]. In connection with these Boolean algebras $F_{n}(T), n \in \omega$, the A.D. Taimanov's question is well known (can be found in the works [9]):

$\left(^{*}\right)$ What properties should have to have the Boolean algebras $B_{n}, n \in \omega$, to exist a complete theory $T$, such that $B_{n}$ is isomorphic to $F_{n}(T), n \in \omega$ ?

We will say that the question $(*)$ is solved positively for the complete theory $T$, if there exists a sequence of Boolean algebras $B_{n}, n \in \omega$, such that $B_{n}$ is isomorphic to $F_{n}(T), n \in \omega$.

It is well known, that in some cases working with Jonsson theories we have the opportunity to restrict ourselves to existential formulas and existentially closed models of the considered Jonsson theory. In this case, instead of the Lindenbaum-Tarskian algebras $F_{n}(T), n \in \omega$, one should consider lattices of existential formulas $E_{n}(T), n \in \omega$. Thus, the above of A.D.Taimanov's question can be formulated as follows:

(**) What properties must have the lattices $E_{n}, n \in \omega$, that there was Jonsson theory $T$, such that $E_{n}$ is isomorphic to $E_{n}(T), n \in \omega$ ?

Similarly, we will say, that question $\left(^{* *}\right)$ is solved positively for the Jonsson theory $T$, if there exists a sequence of lattices $E_{n}, n \in \omega$, that $E_{n}$ is isomorphic to $E_{n}(T), n \in \omega$.

In connection with these questions $(*),(* *)$ the following results were obtained:

Theorem 2. Let $\operatorname{Fr}(A)$ be a perfect complete for existential sentences Jonsson theory of signature $\sigma_{\Gamma}(A)$.

Then the following conditions are equivalent:

1) a positive solution to question $(* *)$ with respect to the theory $\operatorname{Fr}(A)^{*}$;

2) a positive solution to the question $\left(^{*}\right)$ with respect to the theory of $T^{c}$, where $T^{c}$ is the center of the theory of $T^{*}$.

Proof. We prove from 1) $\Rightarrow 2$ ). Suppose that question $(* *)$ has a positive solution with respect to the theory $\operatorname{Fr}(A)^{*}$. Within theory $T_{\Gamma}(A)=T h_{\nabla}(C, a)_{a \in A} \cup\{g(a)=a \mid a \in A\} \cup g(c) \cup T_{g} \cup\{P(c)\} \cup\left\{{ }^{\prime \prime} P \subseteq^{\prime \prime}\right\}$ we can see, that $\operatorname{Fr}(A)^{*}$ is generally speaking uncomplete theory, but is Jonsson due to consistency with $T_{\Gamma}(A)$. Then 
it has a center, let it be equal to $\left(\operatorname{Fr}(A)^{*}\right)^{*}$. Then by virtue of the perfect theory $\operatorname{Fr}(A)$, its center $\operatorname{Fr}(A)^{*}$ will also be perfect in the new signature $\sigma_{\Gamma}(A)$. Then by virtue of the perfect any formula with respect to $\left(\operatorname{Fr}(A)^{*}\right)^{*}$ will be equivalent to some $\exists$-formula by virtue of the model completeness of the theory $\left(\operatorname{Fr}(A)^{*}\right)^{*}$. But this theory is complete. Therefore, since the question $\left(^{* *}\right)$ has a positive solution, the question $\left(^{*}\right)$ will have a positive solution, since the lattice $E_{n}\left(\operatorname{Fr}(A)^{*}\right)$ is a Boolean algebra by virtue of facts 1,2 . By the construction of $\operatorname{Fr}(A)^{*}, T^{*}$ in the new signature $\sigma_{\Gamma}(A)$ is also consistent with $T_{\Gamma}(A)$ as $\operatorname{Fr}(A)^{*}$. By virtue of existentially closed of $M$, where $M$ is equal to $\operatorname{dcl}(A)$, this means, that question $\left(^{* *}\right)$ has a positive solution concerning the theory $\operatorname{Fr}(A)^{*}$ if and only if, it has a positive solution concerning the theory of $T^{*}$ in the new signature $\sigma_{\Gamma}(A)$. It remains to apply Fact 1 and Fact 2 again regarding to $T^{*}$ and $T^{c}$, i.e. by the model completeness of $T^{c}$ we can conclude, that $E_{n}\left(T^{*}\right)$ is a Boolean algebra and, accordingly, the positive question $(*)$ is solved for the theory $T^{c}$.

Now we prove from 2$) \Rightarrow 1$ ). Suppose the opposite, i.e. question $\left(*^{*}\right)$ has not positive solution for the theory $\operatorname{Fr}(A)^{*}$. This means, that for any sequence of lattices $E_{n}\left(\operatorname{Fr}(A)^{*}\right)$ of Jonsson theory $\operatorname{Fr}(A)^{*}$, it is true, that $E_{n}$ is not isomorphic to $E_{n}\left(\operatorname{Fr}(A)^{*}\right), n \in \omega$. But this is incorrect because the question (*) is satisfied for $T^{c}$ and, accordingly, for $\left(\operatorname{Fr}(A)^{*}\right)^{*}$ because of their consistency with $T_{\Gamma}(A)$. And since $\operatorname{Fr}(A)^{*} \subseteq\left(\operatorname{Fr}(A)^{*}\right)^{*}$, we have a contradiction with our assumption, since we can take as a sequence of lattices a sequence of Boolean algebras from a positive solution of the question $\left(^{*}\right)$ for $\left(\operatorname{Fr}(A)^{*}\right)^{*}$.

Theorem 3. Let a theory $T$ be a perfect Jonsson strongly convex theory and let it be existentially prime. $A$ is as in the previous Theorem 1 and $\operatorname{Fr}(A)$ is existentially prime perfect Jonsson strongly convex fragment.

Then the following conditions are equivalent:

1) $\operatorname{Fr}(A)^{*}$ has a core model;

2) $\operatorname{Fr}(A)^{c}$ has a core model;

3) theory $T$ has a core model.

Proof. We prove from 1) $\Rightarrow 2)$. Let $\operatorname{Fr}(A)^{*}$ has a core model. Since $\operatorname{Fr}(A)^{*} \subseteq\left(\operatorname{Fr}(A)^{*}\right)^{*}$, the class of models $\operatorname{Mod}\left(\left(\operatorname{Fr}(A)^{*}\right)^{*}\right)$ of the theory $\left(\operatorname{Fr}(A)^{*}\right)^{*}$ is contained in the class of models $\operatorname{Mod}\left(\operatorname{Fr}(A)^{*}\right)$ of the theory $\left(F r(A)^{*}\right.$. Well known [10; 166], that if theory $T$ satisfies joint embedding property in addition to being strongly convex, then the core model of $T$ is unique up to isomorphism. It follows, that $\left(\operatorname{Fr}(A)^{*}\right)^{*}$ has a core model, since $\operatorname{Fr}(A)^{*}$ и $\left(\operatorname{Fr}(A)^{*}\right)^{*}$ are model-consistent, but $\left(\operatorname{Fr}(A)^{*}\right)^{*}=\operatorname{Fr}(A)^{c}$.

We prove from 2$) \Rightarrow 3$ ). Let $\operatorname{Fr}(A)^{c}$ has a core model $K$. Since $\operatorname{Fr}(A)^{*}$ has the property of joint embedding due to the strong convexity of the theory $T$, the model $K$ is unique up to isomorphism and by virtue of the fact, that $\left(\operatorname{Fr}(A)^{*}\right)^{*} \subseteq T^{*}$ in the language of the new signature $K \in \operatorname{ModT}$.

We prove from 3$) \Rightarrow 1$ ). Let a theory $T$ have a core model $K$. Since the theory $T$ is strongly convex and admits the property of joint embedding, this model $K$ is unique up to isomorphism. Since $C$ is a semantic model of the theory $T$, then $K$ is isomorphically embedded into $C$. Let a model $M \in E(T)$, be such that $A=d c l(M)$. We know, that the theory $\operatorname{Th} h_{\forall \exists}(M)=\operatorname{Fr}(A)^{*} \subseteq \operatorname{Th} h_{\forall \exists}(C)$. Suppose, that $\operatorname{Fr}(A)^{*}$ have not a core model, but due to the existential primeness of the theory $T$ there is an algebraic prime model $P$ and $P \in E(T)$. In the model $C$ there is a substructure $K^{\prime}$, which is an isomorphic image of model $K$ and which is a core substructure of the theory $T$. Since the theory $T$ is perfect, $E_{n}(T)$ is a Boolean algebra and, $T^{*}=T h(C)$ is a model-complete theory, i.e. any formula in the language of the theory $T^{*}$ is equivalent to some $\forall$ formula. It follows, that the core substructure $T^{*}$ is the core model of $T^{*}$. But $\operatorname{Mod}\left(T^{*}\right) \subseteq \operatorname{Mod} T$, i.e. $K^{\prime} \in \operatorname{Mod}\left(\operatorname{Fr}(A)^{*}\right)$. Since $\operatorname{Fr}(A)^{*}$ is a Jonsson theory, consistent with $T_{\Gamma}(A)$, follow that $K^{\prime}$ is the core substructure of the semantic model $C^{\prime}$ of the theory $\operatorname{Fr}(A)^{*}$. By virtue of the perfectness and the existential primeness of $\operatorname{Fr}(A)$ it follows, that $K^{\prime}$ is the core model of $\operatorname{Fr}(A)$. But since $C^{\prime}$ a semantic model $\operatorname{Fr}(A)^{*}$, then $K^{\prime}$ is a core model of $\operatorname{Fr}(A)^{*}$.

\section{References}

1 Jonsson B. Universal relational systems / B. Jonsson // Math. Scand. - 1956. - P. 193-208.

2 Jonsson B. Homogeneous universal relational systems / B. Jonsson // Math. Scand. - 1960. - P. $137-142$.

3 Барвайс Дж. Теория моделей: справочная книга по математической логике: [в 4-х ч.]. - Ч. 1. / Дж. Барвайс; под ред. Ю.Л. Ершова; пер. с англ. - М.: Наука, 1982. - 392 с.

4 Ешкеев А.Р. Йонсоновские теории и их классы моделей: моногр. / А.Р. Ешкеев, М.Т. Касыметова. - Караганда: Изд-во КарГУ, 2016. - 346 с.

5 Marker D. Model Theory: In introduction / D. Marker. - New York: Springer-Verlag Inc., 2002. - P. 342. 
6 Mustafin T.G. New concepts of the stability of theories / T.G. Mustafin // Proceedings of the SovietFrench Colloquium on Model Theory. - Karaganda, 1990. - P. 112-125.

7 Palyutin E.A. E*-stable theories / E.A. Palyutin // Algebra and Logic. - 2003. - Vol. 41. - No. 2. P. 194-210.

8 Сикорский Р. Булевы алгебры / Р. Сикорский. - М.: Наука, 1969. - 376 с.

9 Мустафин Т.Г. О булевых алгебрах теорий / Т.Г. Мустафин // Вестн. Караганд. ун-та. Сер. Математика. - 1974. - № 1. - С. 80-84.

10 Kueker D.W. Core structures for theories / D.W. Kueker. - University of Maryland, College Park, Maryland, 1973. - P. 155-171.

\title{
А.Р. Ешкеев, М.Т. Омарова \\ Йонсон теориясының дөңес фрагменттерінің централдық типтері
}

\begin{abstract}
Мақалада мінсіз йонсон теориясының дөңес фрагменттерінің орталық типтері қарастырылған. Осы жұмыстың негізгі мақсаты - А.Д. Таймановтың мәселені қайта анықтау толық теориялар үшін тұрақты йонссон теориясының семантикалық моделі йонссон фрагменттері саласына формалды анықталған ішкі жиын екенін қайта анықтау. Сондай-ақ сигнатураны жеткілікті түрде байытудағы йонсондық теория мен центрдің арасындағы байланыстар қарастырылды. Бұл жағдайда зерттелген теориялар мұрагерлік болып табылады. Алгебралық тұйықталу анықталған тұйықталумен сәйкес келеді деп болжанды. Қарастырылатын йонсондық теорияларға көрсетілген шектеулер шеңберінде осындай теориялар үшін ядролық модельдердің бар болуы туралы нәтижелер алынды.
\end{abstract}

Kiлm сөздер: йонсондық теория, семантикалық модель, экзистенциалды жай теория, предгеометрия, модельді компаньон, ядролық модель.

\section{А.Р. Ешкеев, М.Т. Омарова}

\section{Центральные типы выпуклых фрагментов совершенной йонсоновской теории}

В работе рассмотрены центральные типы выпуклых фрагментов совершенной йонсоновской теории. Основная цель данной работы - переопределение вопроса А.Д. Тайманова для полных теорий в сферу йонсоновских фрагментов формульно определимых подмножеств семантической модели фиксированной йонсоновской теории. Также рассмотрены связи между центром и йонсоновской теорией в допустимом обогащении сигнатуры. При этом рассматриваемые теории являются наследственными. А также предполагается, что алгебраическое замыкание совпадает с определимым замыканием. В рамках указанных выше ограничений на рассматриваемую йонсоновскую теорию получены результаты о существовании ядерных моделей для таких теорий.

Ключевые слова: йонсоновская теория, семантическая модель, экзистенциально простая теория, предгеометрия, модельный компаньон, ядерная модель.

\section{References}

1 Jonsson, B. (1956). Universal relational systems. Math. Scand.

2 Jonsson, B. (1960). Homogeneous universal relational systems. Math. Scand. 
3 Barwise, Ed.J. (1982). Teoriia modelei: Spravochnaia po matematicheskoi lohike /Theory of models: Reference book on mathematical logic]. (Part 1-4; Part 1). Yu.L. Yershov (Ed.) Moscow: Nauka [in Russian].

4 Yeshkeyev, A.R. \& Kassymetova, M.T. (2016). Yonsonovskie teorii i ikh klassy modelei [Jonsson theories and their classes of models]. Karaganda: Izdatelstvo KarHU [in Russian].

5 Marker, D. (2002). Model Theory: In introduction. New York: Springer-Verlag. Inc.

6 Mustafin, T.G. (1990). New concepts of the stability of theories. Proceedings of the Soviet-French Colloquium on Model Theory.

7 Palyutin, E.A. (2003). E*-stable theories. Alhebra i lohika - Algebra and Logic, 41, 2, $194-210$.

8 Sikorsky, R. (1969). Bulevy alhebry [Boolean algebras]. Moscow: Nauka [in Russian].

9 Mustafin, T.G. (1974). O bulevykh alhebrakh teorii [On Boolean algebras of theories]. Vestnik Karahandinskoho universiteta. Seriia Matematika - Bulletin of the Karaganda University. Mathematics Series, 1, 80-84. Karaganda: KSU [in Russian].

10 Kueker, D.W. (1973). Core structures for theories. University of Maryland, College Park, Maryland. 